\title{
IMPROVEMENT OF CONSTRUCTION LABOR PRODUCTIVITY IN CHAMBAL REGION
}

\author{
Vaishant Gupta ${ }^{1}$, R. Kansal ${ }^{2}$ \\ ${ }^{I}$ M.E. Student Civil Department MITS Gwalior 474005 \\ ${ }^{2}$ Professor and Head Civil Engineering Department MITS Gwalior 474005
}

\begin{abstract}
In construction industry labor cost 30 to $50 \%$ of total cost of project. In Chambal Region (M.P.) construction industry is facing the problems of low productivity. The aim of this study, therefore, is to identify and rank the relative importance of factors perceived to affect labor productivity on construction sites. To achieve this objective, professional such as Project Manager, Project Engineer, Site Engineer, Architect, Assistance Project Manager, Assistance Project Engineer and other who work on the project from management to execution level, were invited to participate in a questionnaire survey. In questionnaire, factors were divided in four primary groups such as (1) management; (2) technological; (3) human/labor; and (4) external. After the analysis of questionnaire we find top ten following factors which effect on construction labor productivity in Chambal Region such as : (1) Clarification in Technical Specifications; (2) Labor Supervisions; (3) Method of construction; (4) Delay in Payment; (5) Labor Fatigue; (6) lack of construction managers leadership; (7) extents of variations/change order during executions; (8) late arrival, early quit, and frequent unscheduled breaks; (9) Labor Skill; and (10) Availability of Experienced Labor. The results obtained can be used by construction professional to take care of labor productivity in construction projects.
\end{abstract}

\section{INTRODUCTION}

Several studies have conducted on construction labor productivity in past time. Some studies related to find the factors affected on labor productivity on construction industry. Basic aim of the study was calculated and measured affected of these factors in planning and scheduling of the construction project.

But we could not get any standardized method for calculated and measured loss of labor productivity in construction industry from past studies.

Detailed study of actual labor cost is required for achieved better labor productivity. All the labor do not affect same level on productivity. Different type's labor have different affecting level on productivity. The basic and main concern of project for any organization are high productivity, low cost, better quality, and least time. We cannot imagine about get good productivity without high technology machine and tools, skilled manpower and easily availability of materials and another important point is better management at construction site.

In today's era, good labor productivity is biggest point of perturbing of any organizations. There are number of ways defined productivity. Several researcher defined productivity in his own ways. In general productivity is ratio of output and input. Resources are input in construction industry and ready to use structure is output.

Construction industry is depend on 3-M resources. There are means of 3-M is manpower, machine and materials. 3-M are basic input in construction industry. Manpower is main and precious resource of construction industry. If we consider only manpower as an input in productivity, then productivity will be called construction labor productivity. Construction labor productivity is most frequently research topic for construction field researcher. A reason behind it because of labor cost are around 30-50\% of total cost of project.

In Chambal Region, the construction industry facing many challenges, but one of the most important is low productivity. Mostly project in Chambal Region are running over budget. Despite all the new technological advancements, easily availability of construction materials, tools and financially strong local contractors.

Pick out and rank the relative importance factors affected construction labor productivity in Chambal region is the objective of this study, so that the result can be used for those person who want to start a mega projects and have not a sufficient knowledge about construction industry of Chambal Region. This study will be also helpful for experience construction professional for executing the project with good labor productivity.

In general definition of productivity is ratio of output and input. There are few definition of productivity

(1) According to Borcherding and Liou 1986, "productivity" express the relationship between outputs and inputs.

(2) According to Drewin 1982, the definition of labor productivity is the amount of good and services produced by a productive factor (manpower) in the unit of time.

(3) According to Sumnath 1984, the definition of productivity as a quotient obtained by dividing the output by one of the productivity factors. 
(4) According to Adrian 1987, the productivity as "dollars of output per person-hour of labor productivity."

(5) According to Jarkas 2005, the productivity as the "faculty to produce," that is, the desire to produce.

Productivity further classified in two types:-

A. Total Factor Productivity (TFP)

B. Partial Factor Productivity (PFP)

Firstly Total Factor Productivity is defined as the ratio of outputs to summation of inputs, and is expressed as:-

\section{TFP=TOTAL OUTPUT/SUM OF TOTAL INPUT}

Partial Factor Productivity establishes a relationship between outputs and a single or selected inputs. Equation 1a, $1 \mathrm{~b}$ and $1 \mathrm{c}$ expressed example of partial factor productivity.

Labor Productivity = Output Quantity/Labor Hours $\quad$ 1a

Capital Productivity = Output Quantity/Capital Input $\quad 1 \mathrm{~b}$

Equipment Productivity = Output quantity/Equipments Hours 1c

\section{Factor Affecting on Labor Productivity}

Forty Five factors identify by literature survey, which affected labor productivity are classified under the four primary groups (1) Management Group (2) Technological Group (3) Human/Labor Group (4) External Group.

\subsection{Management Group}

Management group have 24 following factors:-

1. Labor Supervision

2. Method of Construction

3. Delay in Payment

4. Lack of Construction Manager Leadership

5. Late Arrival, Early Quit and Frequent Unscheduled Breaks.

6. Sequence of Work

7. Communications Between Site Management and Labor

8. Storage Locations

9. Labor Interference and Congestion

10. Incentive Scheme

11. Unrealistic Scheduling and Expectation of Labor Performance

12. Lack of Recognition Program

13. Unavailability of Suitable Tools

14. Proportions of Work Subcontracted

15. Delay in Inspection by Site Management

16. Material Shortage

17. Lack of Training Offered to Operatives

18. Lack of Periodical Meeting with Crew Leader

19. Lack of Suitable Rest Area Offered to labor on Site

20. Crew Size and Composition

21. Working Overtime

22. Lack of Providing Labor With Transportations
23. Owner's Representative Intervention with Site Management and Operatives

24. Accidents as a Results of Poor Site Safety Program

\subsection{Technological Group}

Technological group have 12 following factors:-

1. Clarification in Technical Specifications

2. Extents of Variations/Change Order During Executions

3. Team Spirits

4. Delay in Responding to Requests for Information's

5. Rework

6. Stringent Inspection by The Engineer

7. Delay in Inspection by The Engineer

8. Site Restricted Access

9. Design Complexity Level

10. Compatibility and Consistency Among Contract Documents

11. Confinement of Working Space

12. Layout of Site

\subsection{Human/Labor Group}

Human/Labor group have 4 following factors:-

1. Labor Fatigue

2. Labor Skill

3. Availability of Experienced Labor

4. Labor Motivation

\subsection{External Group}

External group have 4 following factors:-

1. High/Low Temperature

2. Sandstorms

3. Rain

4. High Humidity

5. High Winds

\section{METHODOLOGY}

Questionnaire survey was carried out among the various construction professionals. The Questionnaire consists of two parts. First part consist with general information of respondents. Second's part consists with set of questions targeting the factors affecting labor productivity in the four different groups that is management group, technological group, human/labor group and external group. The responses were to be based on the understanding, knowledge and experience of the respondents and not related to any particular project.

\section{DATA ANALYSIS}

During the questionnaire survey, 37 professionals from construction industry have responded. Table 1 represents the scale used for representation of effect different factors on labor productivity used in questionnaire survey. 
Table 1 Scale Used for Representation of effect

\begin{tabular}{|l|l|l|l|l|l|}
\hline \multicolumn{6}{|l|}{ Effect of factor on labor productivity } \\
\hline $\begin{array}{l}\text { Types } \\
\text { of } \\
\text { effect }\end{array}$ & $\begin{array}{l}\text { No } \\
\text { effect }\end{array}$ & $\begin{array}{l}\text { Little } \\
\text { effect }\end{array}$ & $\begin{array}{l}\text { Moderate } \\
\text { effect }\end{array}$ & $\begin{array}{l}\text { Strong } \\
\text { effect }\end{array}$ & $\begin{array}{l}\text { Very } \\
\text { strong } \\
\text { effect }\end{array}$ \\
\hline Scale & 1 & 2 & 3 & 4 & 5 \\
\hline Factors & $\mathrm{n} 1$ & $\mathrm{n} 2$ & $\mathrm{n} 3$ & $\mathrm{n} 4$ & $\mathrm{n} 5$ \\
\hline
\end{tabular}

In order to facilitate the study, after the literature review and personal interviews, a plan was formulated for collecting field information and creating an evaluation process and numerical values. R.I.I. method used for analysis the survey results.

\section{R.I.I. $=5 \underline{5(n)+4(n 4)+3(n 3)+2(n 2)+1(n 1)} \times 100$ $5(n 1+n 2+n 3+n 4+n 5)$}

Where

$\mathrm{n} 1=$ number of respondents who selected factor for no effect $\mathrm{n} 2=$ number of respondents who selected factor for little effect

$\mathrm{n} 3=$ number of respondents who selected factor for moderate effect

$\mathrm{n} 4=$ number of respondents who selected factor for strong effect

$\mathrm{n} 5=$ number of respondents who selected factor for very strong effect

\section{RESULTS AND DISCUSSION}

Based on R.I.I. top ten factors affecting labor productivity in the Chambal Region are presented in table 2.

Table 2 Top Ten Factors Affecting Labor Productivity

\begin{tabular}{|l|l|l|l|}
\hline $\begin{array}{l}\text { Ran } \\
\mathrm{k}\end{array}$ & Factor & R.i.i. & $\begin{array}{l}\text { Related } \\
\text { group }\end{array}$ \\
\hline 1 & $\begin{array}{l}\text { Clarification in technical } \\
\text { specifications }\end{array}$ & 76.21 & $\begin{array}{l}\text { Technologica } \\
1\end{array}$ \\
\hline 2 & Labor supervision & 74.59 & Management \\
\hline 3 & Method of construction & 74.05 & Management \\
\hline 4 & Delay in payments & 72.97 & Management \\
\hline 5 & Labor fatigue & 72.43 & Human/labor \\
\hline 6 & $\begin{array}{l}\text { Lack of construction } \\
\text { managers leadership }\end{array}$ & 71.89 & Management \\
\hline 7 & $\begin{array}{l}\text { Extents of varitions/change } \\
\text { order during executions }\end{array}$ & 71.35 & $\begin{array}{l}\text { Technologica } \\
1\end{array}$ \\
\hline 8 & $\begin{array}{l}\text { Late arrival, early quit and } \\
\text { frequent unschedule breaks }\end{array}$ & 70.81 & Management \\
\hline 9 & Labor skills & 69.72 & Human/labor \\
\hline 10 & $\begin{array}{l}\text { Availabilty of experienced } \\
\text { labor }\end{array}$ & 69.18 & Human/labor \\
\hline
\end{tabular}

The Clarification in Technical Specifications factor ranked $1^{\text {st }}$ among the 45 factors have R.I.I. $76.21 \%$. So it is most important factor affecting construction labor productivity in Chambal Region. Lack of clarity in technical specification become a cause's disturbance in the work progress.
Continuous request for clarification is required in case of unclear and incomplete technical specifications.

Labor Supervision factor ranked $2^{\text {nd }}$ among all 45 factors with R.I.I. 74.59\%. Supervisor is a link between managements and workforce. Supervisor is directly responsible for productivity and activity of labors. Supervisor have responsibility to manage workforce. He is responsible for work to be complete with time and as per specifications.

The $3^{\text {rd }}$ rank factor is Method of Construction with a R.I.I. $74.05 \%$. Effect of Construction method is related to way of working. It depend on intelligence of people those who work on the project. The wrong method of work is very harmful. It may be result in cost and time overrun.

Delay in Payment factor ranked $4^{\text {th }}$. Without smooth financial flow we cannot imagine good productivity of project. A time to time payment will motivate labor.

Labor Fatigue factor ranked $5^{\text {th }}$. Fatigue is created due to long working hours. Fatigue decrease the concentration on work, which reduce the productivity. Fatigue can be reduce by periods of rest.

Lack of Construction Manager's Leadership, with a R.I.I. $71.89 \%$ is ranked $6^{\text {th }}$. It indicates the importance of construction manager's leadership to improve the labor productivity.

Extents of Variation/Change Orders during Execution rank $7^{\text {th }}$ among all45 factors, with R.I.I. $71.35 \%$. Suppose that construction of wall is completed and after that architect come and say to fix a window on this wall. Obviously work is to be done again. And it will be effect on labor productivity.

The $8^{\text {th }}$ ranked factor is late arrival, early quit and frequent unscheduled breaks, have R.I.I. $70.81 \%$.There is fixed time for work at the site, if labor comes late so obviously work will be start late, if labor quit early from the time so workable time will be short.

Skilled and Availability of Experienced Labor Factors rank $9^{\text {th }}$ and $10^{\text {th }}$ with R.I.I. $69.72 \%$ and $69.18 \%$ respectively. Specialization and expert in work define a worker to be skilled. Increasing demand of skilled labor due to use of technology at construction sites such as computerized high tech machine and plant will increase labor productivity.

\section{CONCLUSION AND RECOMMENDATIONS}

Basic knowledge of construction labor productivity during execution of project can save money and time. Investment and risks in construction industry are very high because of complexity and long lasting duration of projects. Two basic drawback of construction industry are "time overrun and Cost overrun" of the project. Low labor productivity is basic reason behind of these. In the present study all possible factors which may effect on construction labor productivity 
are identified. Ranking of factors is done using the Relative Important Index method. The basic objective of this study is to study various factors affecting labor productivity on construction industry in Chambal Region.

Following are the recommendations for improving labor productivity in the construction industry.

I. Detail of every work should be present at site. Every work should be well specified.

II. Effective Labor supervision increases labor productivity. Supervisor should be made responsible for the productivity

III. Construction method should be in such a way so that labor can complete work with more productivity.

IV. Payment should be made timely without delay.

V. Uses of worker should not be more than 8 hours/day and 40 hours/week. Because after the 8 hours efficiency of worker has been less than $90 \%$, and maybe he will presence at site physically but not mentally due to physical fatigue. If we wants use overtime at site we should use other batch of labor after each 8 hours slots.

VI. Make a group of each task and each group should have a leader. Leader of the group will be responsible for productivity of his group. Behaviors of leader should be friendly with team member.

VII. To achieve desired results, time required in implementing changes orders should be estimated and scheduled without affecting the project time completion. Regular meeting should be arranged with the project authorities.

VIII. Time table of worker at site should be strictly maintained. Engagement of worker in nonproductive task should be less during work time. Special focus should be on late arrival, early quit and frequents break during working time. It can save loss of productivity.

IX. Labor at site should be skilled and experienced. Good productivity cannot be imagine without skilled and experienced labor.

\section{REFERENCES}

[1] Adrian, J. (1987). Construction productivity improvement, Elsevier Science Publishing, Amsterdam, The Netherlands.

[2] Borcherding, J. D., Sebastian, S. J., and Samelson, N. M. (1980). "Improving motivation and productivity on large projects." J. Constr. Div. 106(1), 73-89.

[3] Enshassi, A., Mohamed, S., Abu Mustafa, Z., and Mayer, P. (2007). "Factors affecting labour productivity in building projects in the Gaza strip." J. Civil Eng. Manage. 13(4), 245-254.

[4] Horner, R. M.W., Talhouni, B. T., and Thomas, H. R. (1989). "Preliminary results of major labour productivity monitoring programme." Proc. of the 3rd Yugoslavian Symp. On Construction Management, Cavtat, 18-28.

[5] Jarkas, A. M. (2005). "An investigation into the influence of buildability factors on productivity of in situ reinforced concrete construction." Ph.D. thesis, Dept. of Civil Engineering, Univ. of Dundee, Dundee, UK.

[6] Lim, E., and Alum, J. (1995). "Construction productivity: Issues encountered by contractors in Singapore.” Int. J. Proj. Manage. 13(1), 51-58.

[7] McTague, B., and Jergeas, G. (2002). Productivity improvements on Alberta major construction projects, construction productivity improvement report/project evaluation tool, Alberta Economic Development, Alberta, Canada.

[8] Neil, J. M., and Knack, L. E. (1984). "Predicting productivity." Transactions of American Association of Cost Engineers, H.3.1-H.3.8.

[9] Sumanth, D. J. (1984). Productivity engineering and management, McGraw-Hill, New York.

[10] Talhouni, B. T. (1990). "Measurement and analysis of construction labour productivity." Ph.D. thesis, Dept. of Civil Engineering, Univ. of Dundee, Dundee, UK.

[11] Thomas, H. R., Maloney, W. F., Horner, R. M. W., Smith, G. R., Handa, V. K. 